\title{
The Unified Patent Court: where are we and what should you be doing?
}

\author{
Rowan Freeland*,1 \\ ${ }^{1}$ Simmons \& Simmons LLP, CityPoint, 1 Ropemaker St, London EC2Y 9SS, United Kingdom \\ * Author for correspondence: rowan.freeland@simmons-simmons.com
}
"Setting up an international patent court, where the entire 'bundle' of European patents can be enforced in a single set of proceedings, is more complicated, but in $2013-35$ years after the European Patent Office opened for business - an agreement was signed which would set up a 'Unified Patent Court' (UPC) which could determine patent disputes in nearly all EU member states."

The road to the Unified Patent Court, which will allow industry to enforce its patents in Europe in a single set of proceedings rather than in numerous national courts, is becoming increasingly rocky as the project approaches its goal. This article reviews the rocks encountered in the past year and looks forward to what industry now needs to be addressing as the summit approaches.

First draft submitted: 20 June 2017; Accepted for publication: 4 July 2017; Published online: 12 October 2017

Keywords: patents • ratification $\bullet$ Unified Patent Court • unitary patent

\section{The Unified Patent Court}

When you want a patent in Europe, you can file a single application at the European Patent Office. The resulting patent will be the same in every country for which you comply with the necessary formalities (and pay the fee). However, if somebody infringes your patent, you then have to sue in each country separately: my own record is supporting a client in suing to enforce the same patent in separate proceedings in 27 different European countries. Setting up an international patent court, where the entire 'bundle' of European patents can be enforced in a single set of proceedings, is more complicated, but in 2013 - 35 years after the European Patent Office opened for business - an agreement was signed which would set up a 'Unified Patent Court' (UPC) which could determine patent disputes in nearly all EU member states.

At least 13 signatory states have to ratify the UPC agreement for the new court to come into being, including UK, France and Germany. In June 2016, a sufficient number of signatory states were on course to ratify, and the final instrument, the Protocol on Privileges and Immunities (necessary for putting the international court outside the reach of local laws) was about to be finalized.

Linked to the UPC is a Unitary Patent, a European patent designated for all the member states of the UPC as a single patent, rather than a separate patent for each country. The implementation of the Unitary Patent depends on the implementation of the UPC.

\section{The impact of Brexit}

The decision in the Brexit referendum threw matters into confusion, because the prevailing view was that only EU member states could be members of the new court. A number of lawyers closely involved with the UPC project argued that this was not necessarily the case. As a reality check, a consortium of industry and professional bodies, which I coordinated, obtained an Opinion from specialist EU constitutional barristers, who had no invested interest in patents. Their view was that, subject to certain preconditions, a non-EU member state could be a member of 
the UPC. This encouraged industry groups to lobby the government to do what it could to secure long-term UK participation in the UPC.

In November 2016, the UK government announced that it would ratify the UPC agreement, but it made no statement as to whether it would negotiate for the UK to remain a member following Brexit; this is the subject of ongoing lobbying and assessment. A further delay followed for the preparation of the necessary statutory instrument which needed to be passed by parliament before UK ratification could take place. The draft instrument has to be laid before Parliament for a period of 40 days in order to be passed; unfortunately, the 40-day period was interrupted by the UK general election in June, and the Instrument died with the dissolution of Parliament. However, in the new Parliament, the draft Instrument was re-laid in the week of 19 June. The 40-day period will leapfrog the summer recess and the Instrument is expected to be passed in late October. The UK government can then proceed to ratify the UPC agreement.

\section{Provisional application}

The UPC Agreement provides that the court will open for business 4 months after ratification. It was appreciated that this gave too little time for the necessary administrative arrangements, and although some preparatory work could be done in advance, it was recognized that a longer preparatory period would be needed. Accordingly, in October 2015, the signatories of the UPC agreement agreed a protocol on provisional application. This provides that, when at least 13 states (including, again, UK, France and Germany) indicate that they are in a position to ratify, the administration of the court can be set up, and the appointment of judges and recruitment of court staff can then take place, together with the implementation of the computerized case management system. Formal ratification (Germany will probably be the country which takes the number over the required threshold) can then take place when it is clear that the preparations are on course. At the time of writing, the UK government was expected to make the necessary declaration before the end of June.

Other signatory states have been taking their time to make their declarations (which in many countries require parliamentary approval) and in early June the target date for entry into operation for the UPC, envisaged for December 2017, was delayed. It was expected that the court would open for business in late spring 2018.

\section{The German constitutional issue}

The final spanner in the works came from Germany. On 12 June, the President of the German Constitutional Court notified the German government that it should suspend all steps toward implementation of the UPC agreement. This was because of a challenge made by a German lawyer that ratification of the agreement would be contrary to the German constitution, which had been assessed informally by the President of the Court, who had decided that it is not clearly inadmissible. He has accordingly referred the challenge to the Full Court for assessment, first, of its admissibility and then, if admissible, on the merits.

The complaint has been circulated in confidence for comment to certain lawyer organisations; it appears that this is prior to the decisin on admissibility, although this is nowhere publicly stated. It is understood that the Court appreciates the timing issues, and it is hoped that a final decision will be reached by the middle of next year. However, if European law issues are raised (and the complainant has published articles suggesting that UPC Agreement is contraty to EU law), questions could be referred to the Court of Justice of the European Union. If the German Court considers that this is required, it will delay a decision for as much as 2 years. The German Constitutional Court upholds only a tiny fraction of the challenges brought before it, but since each application is assessed on its own merits, that is not necessarily of much comfort.

\section{Opting out}

The UPC agreement provides that owners of European patents can opt them out of the jurisdiction of the UPC (which would mean that they can be litigated only in the national courts on a country-by-country basis). In practice, the advantage of filing an opt-out is that the patent cannot be challenged for invalidity in the UPC; this is considered important by many companies, particularly in the biopharma industry, who are nervous about seeing their patents challenged in a new court where it is not clear how the procedure will work in practice or how the judges will decide cases.

An opt-out can be withdrawn, allowing the patentee to sue for infringement in the UPC, provided that proceedings involving the patent have not been started in a National Court. Since such proceedings can be started 
by a third party attacker, for example, challenging validity, a patentee who opts out with the intention of withdrawing the opt-out at a future date runs the risk that the patent will be 'pinned' in the national system.

Because an opt-out is ineffective if proceedings in the UPC (e.g., by a competitor filing an invalidity challenge) have already been started, there will be a 'sunrise period' of, probably, 3 months during which opt outs can be filed ahead of the court's opening.

\section{What should businesses now be doing?}

In view of the setbacks summarized above, it is not surprising that many people in industry have decided to do nothing about the UPC until its future, and the timing of that future, becomes clearer. It is nevertheless important to bear in mind that businesses need to give some careful long-range thoughts to the advantages and challenges which the UPC will bring. In particular:

- The UPC needs to form part of the strategic decision-making process of anyone contemplating patent litigation in Europe in 2018. This is the case not just for multi-national patent disputes where infringement occurs in multiple jurisdictions. The UPC also provides an alternative forum for national proceedings, and for cases involving domestic infringement, litigants will have a choice between the national courts and the UPC. In some cases, the procedures of the UPC, which differ from national litigation procedures, may offer advantages even for small cases.

- Litigation in the UPC places a greater emphasis on front-loaded written pleadings and evidence than parties will have experienced in the UK courts. The procedure is designed to be fast, with the court aiming to hear cases and give a first instance decision on merits within 12 months. There is a strong focus on written procedure with those bringing both infringement and revocation proceedings required to set out their detailed case in writing at an early stage of proceedings. This means that patentees will need to plan ahead, and those who are sued will need to respond rapidly to meet deadlines.

- Opting out and preventing withdrawals of opt-outs will add a new dimension to the strategic planning of patent litigation, even for those who may not necessarily plan to use the court. There is potential for patentees and potential infringers to make strategic forum choices. These need to be considered carefully in advance as some of the ramifications can be complex.

- The UPC permits interim injunctions to be issued where there is an imminent threat of infringement. In some countries, it may be easier to obtain an injunction in the UPC than in the national court - and there may be differences in approach between the different divisions of the UPC, at least in the early days. This creates opportunities for patentees to make strategic forum choices in order to maximize the prospects of obtaining an injunction.

- Protective letters are now important across Europe, not just in Germany, Switzerland, The Netherlands and Belgium. A protective letter setting out the defendant's arguments may be filed by a prospective defendant at the UPC in anticipation of an application for an interim injunction being lodged by a patentee. Whether any protective letter has been filed is one of the factors that the court will take into account when deciding whether to grant an injunction without hearing the defendant or whether an oral hearing is required. Protective letters are an important strategic tool for potential defendants and something that ought to be considered before the UPC comes into operation.

\section{Conclusion}

It has been a long and rocky road to the Unified Patent Court. Every time the destination is within reach, something happens to delay it. But unlike Sisyphus, we do not have to start again from the beginning, and every setback sees us nevertheless a little further along the road. We are near the time when businesses need to start active preparations.

Financial \& competing interests disclosure

The author has no relevant affiliations or financial involvement with any organization or entity with a financial interest in or financial conflict with the subject matter or materials discussed in the manuscript. This includes employment, consultancies, honoraria, stock ownership or options, expert testimony, grants or patents received or pending, or royalties.

No writing assistance was utilized in the production of this manuscript. 
